\title{
Effect of Polarized Light Treatment on Milk Production and Milk Somatic Cell Count of Cows
}

\author{
M. FENYÖ ${ }^{1}$, G. SZITA², J. BARTYIK ${ }^{3}$, J. DÓRA ${ }^{1,}$ S. BERNÁTH ${ }^{4}$ \\ ${ }^{1}$ Polárium Ltd., Hungary \\ ${ }^{2}$ Szent István University, Faculty of Veterinary Science, Department of Food Hygiene \\ ${ }^{3}$ Agrár Co. Ltd. of Enying, Hungary \\ ${ }^{4}$ Institute for Veterinary Medicinal Products, Hungary \\ Received March 15, 2006 \\ Accepted March 13, 2008
}

\begin{abstract}
Fenyő M., G. Szita, J. Bartyik, J. Dóra, S. Bernáth: Effect of Polarized Light Treatment on Milk Production and Milk Somatic Cell Count of Cows. Acta Vet. Brno 2007, 77: 225-229.

Treatment with linearly polarized light (LPL) is a widely used and recognized therapeutic method in human medicine for healing wounds, ulcers and a variety of other dermatological problems. Polarized light mobilizes the inadequately functioning defence mechanisms of the human body. The aim of the present experiment was to investigate the effect of LPL treatment on the udder of milking cows.

Before the start of treatment, there was no significant difference between cows to be treated with LPL and the control cows in mean somatic cell counts (SCC) of milk samples taken separately by udder quarter and in the mean milk yield. The LPL treatment lasted for $20 \mathrm{~min}$ and was performed twice a day over a period of one month. Before treatment, the mean SCC of milk was $3.47 \times 10^{5}$ \pm 910 in the group to be treated and $4.07 \times 10^{5} \pm 920$ in the control group. In a six-week period immediately after treatment, the mean SCC of the treated and the control group was $1.32 \times 10^{5} \pm$ 825 and $2.63 \times 10^{5} \pm 825$, indicating a significant difference in favour of the treated group.

Before the LPL treatment, the milk yield of cows in the group to be treated was $25.77 \pm 1.2 \mathrm{~kg} /$ day, while that of the control cows was $27.30 \pm 1.4 \mathrm{~kg}$ /day. In a six-week period after treatment, the milk yield of cows in the treated and control groups was $28.83 \pm 1.5 \mathrm{~kg} /$ day and $25.48 \pm 1.4$ $\mathrm{kg} /$ day, respectively. There is a significant difference between these values in favour of the treated group.

The results show that a regular LPL treatment of the udder of cows can significantly reduce the SCC of milk and significantly increase the milk yield. The treatment can be applied during lactation without interfering with the milking regime.
\end{abstract}

Mastitis, somatic cell count (SCC), milk yield of cows, immunostimulation, linearly polarized light (LPL), natural treatment, drug-free therapy

There are many reports in the literature on wound treatment with low-level laser based on biostimulation (Fenyő 1984; Mester et al. 1989). In the early 1980s Márta Fenyő, one of the authors of this study, discovered the biostimulating effect of polarized light (Fenyö 1984). Based on a hypothetical model it was suggested that, irrespective of the wavelength or coherence, polarization was the only specific property of laser responsible for the accelerated healing of wounds. The interaction between the unidirectional electromagnetic field of linearly polarized light (LPL) and the cell membrane can favourably influence membrane activity (Fenyö 1984). An experiment on human embryo fibroblast cultures provided evidence in support of the model. This investigation demonstrated essential structural changes in the plasma membrane after LPL treatment, while after treatment with diffuse light (DL) and in the untreated controls no changes were observed (Kubasova et al. 1988).

To confirm the effectiveness of LPL, a light source emitting LPL was developed for use in the medical treatment of refractory wounds and ulcers. During the past few

\footnotetext{
Address for correspondence:

Dr. Géza Szita

Szent István University, Faculty of Veterinary Science

Department of Food Hygiene

István str. 2

H-1078 Budapest, Hungary
}

Phone: $+36-1-478-5152$
Fax: +36-1-478-4155
E-mail: Szita.Geza@aotk.szie.hu
http://www.vfu.cz/acta-vet/actavet.htm 
decades millions of people have been treated and healed using this natural method of therapy.

Cytological and immunological experiments on wound secretion were conducted to expand our knowledge on the process of wound healing. These experiments have unambiguously demonstrated that LPL stimulates the natural defences of the body and boosts cellular and humoral immune mechanisms against bacterial infections, even against those caused by highly resistant bacteria such as Staphylococcus aureus or Pseudomonas aeruginosa (Fenyő 1984; Kubasova et al. 1988). The effect of LPL and DL on the blast transformation of purified human $\mathrm{T}$ lymphocytes was investigated in vitro. LPL had a pronounced effect, whilst DL had no effect at all, producing results similar to those shown by the untreated control cells (Kubasova et al. 1995).

The objective of a further experiment was to prove the immunostimulating effect of LPL in vivo. The spleen of mice previously inoculated with Ehrlich ascites tumor was treated with LPL and DL. Reduction of the mitotic index was observed in LPL-treated mice, and there was no effect in the case of DL (Kubasova et al. 1995).

Other in vitro findings suggest that LPL influences cytokine production, while exposure to DL of the same energy density has no measurable effect on the indicators studied (Fenyö et al. 2002).

From the above observations it is evident that the stimulating effect exerted on biological systems by polarized light cannot be achieved by diffuse light.

The beneficial effect of polarized light manifests itself in a wide range of fundamental phenomena, such as stimulation of epithelization, acceleration of wound healing, promotion of blood circulation, stimulation of the immune system, abatement of inflammatory processes, prevention and healing of infections, and improvement of blood oxygenation (Fenyö 1984; Mester et al. 1989). On the basis of our experience gained in human medicine, we are convinced that LPL treatment can potentially exert a beneficial effect on the udder of cattle.

A substantial proportion of the dairy cow population world-wide is affected by subclinical mastitis and the incidence of clinical mastitis is also high. Microinjuries to the udder caused by the milking machine predispose cows to the clinical manifestation of mastitis. The milk yield of cows affected by mastitis radically decreases. Summary values in the literature for losses of milk production were estimated as $375 \mathrm{~kg}$ for a clinical case $(5 \%$ of the lactation level) with a 2 -fold increase in the crude somatic cell count (Seegers et al. 2003). According to the calculations, cows infected with Staphylococcus aureus produce on average $583 \mathrm{~kg}$ less milk annually than healthy cows (Ózsvári et al. 2003). An additional source of economic loss is that the milk of cows requiring mastitis medication cannot be used for human consumption either during treatment or during the withdrawal period from the drug applied.

In view of the general biostimulating effect of LPL, we investigated whether polarized light treatment had any favourable influence on the milk yield and milk somatic cell count of cows.

\section{Materials and Methods}

The experiment was conducted on the dairy farm of Enying Agricultural Co. Ltd. (Hungary), on cows of the Holstein-Friesian breed. Milking was done in a herringbone milking parlour. A total of 12 (six treated and six control) cows were used. For the treated and the control group, we selected cow pairs that were as similar to each other as possible in terms of milk SCC, milk yield, parity number and stage of lactation. All the cows selected for the experiment were in the descending phase of lactation, between the $5^{\text {th }}$ and $7^{\text {th }}$ month (average: 6 months).

The somatic cell count (SCC) of milk samples taken separately by udder quarter was determined using Fossomatic ${ }^{\mathrm{TM}} 5000$, a fully automated somatic cell counter based on the Foss Flow Cytometry principle. A quarter of milk was taken after the first $10-15 \mathrm{ml}$ of milk had been discarded. Quarter samples were collected at morning milking. The milk yield was measured in whole milking quantities per cow and expressed in $\mathrm{kg} /$ day units.

Polarized light treatment was performed using a new light source called EFLITE (power on the surface to be 


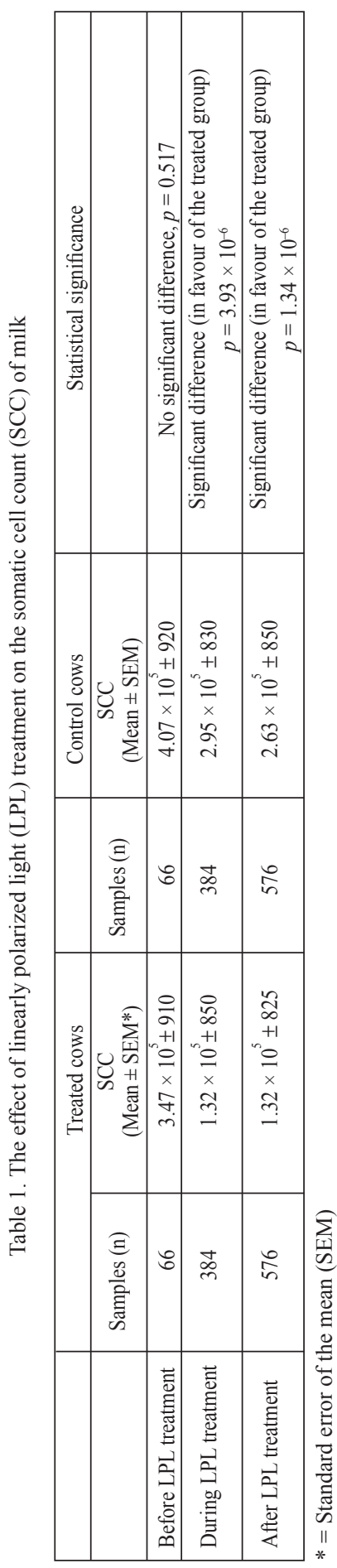

treated: $2 \mathrm{~mW} / \mathrm{cm}^{2}$; operating wavelength spectrum: $400-900 \mathrm{~nm}$, i.e. the visible and near infrared spectral region), which was developed and manufactured recently for veterinary use (Polárium Ltd., Hungary). The treatment was performed as part of the everyday routine of the farm so that it caused no disturbance to the animals and did not interfere with the activities of the farm personnel. The udder of cows was exposed to LPL irradiation of bilateral direction for $20 \mathrm{~min}$ twice a day, from a distance of $30 \mathrm{~cm}$. The treatment was carried out twice a day at the time of milking for one month. After the cow had been positioned in the milking stall, the udder was exposed to LPL for 5 min emitted by EFLITE lamps fixed on the bars separating the milking stalls. Exposure was continued during the $10 \mathrm{~min}$ of milking and for further $5 \mathrm{~min}$ after the teat cups had dropped off.

The experimental period started on April 1, 2004 and lasted for an entire month. The continuing effect of the LPL treatment was monitored in a follow-up period of additional six weeks.

The SCC and milk yield data for the period before the treatment ("preLPL" results) were obtained from the official records kept by the Gödöllö Livestock Performance Testing Ltd. (Hungary) on a monthly basis. The test team used also the monthly official milk yield data of the 12 animals, collected and recorded continuously during the treatment and in the follow-up period. During and after the LPL treatment milk samples were taken by the test team four times a week from all udder quarters of each cow to determine the SCC.

During the treatment and in the follow-up period the test team also recorded the milk yield of cows once a week. As both records applied to the same group of animals, the official and the own-recorded data were pooled and evaluated as "pre-LPL", "during LPL" and "post-LPL" values.

The effect of LPL on the milk yield of cows was evaluated in such a way that the entire period of the experiment was divided into "pre-LPL", "during LPL" and "post-LPL" periods, and when summarizing the data for the statistical evaluation the exact date of sampling within the different data sets (altogether six data sets) was disregarded (this is meant by the term "cumulated by time"). The SCC values of the treated and control groups were cumulated by time for each cow and udder quarter. The data were evaluated using independent-samples $t$-test.

\section{Results and Discussion}

As a result of the LPL treatment, the milk SCC of the treated cows significantly decreased in the period during and after the treatment, compared to the pre-LPL values. Such a decrease could not be observed in the control cows (Table 1).

The LPL treatment resulted in a significant increase in the milk yield of treated cows. The difference in milk yields of the treated and the control cows was significant in the period after the LPL treatment (Table 2).

Mastitis is an inflammatory reaction of the mammary gland to invading pathogens. One of the most apparent reactions is the increased influx of immunoreactive cells from blood into milk, inducing a high increase of milk somatic cell counts. The same occurs in subclinical mastitis, as well (Bruckmaier et al. 2004). The udder quarter somatic cell counts reflect the healthy or inflammatory status of the mammary gland (Schukken et al. 2003).

On the basis of the results obtained and experience gained during this study, we can safely state that the treatment 


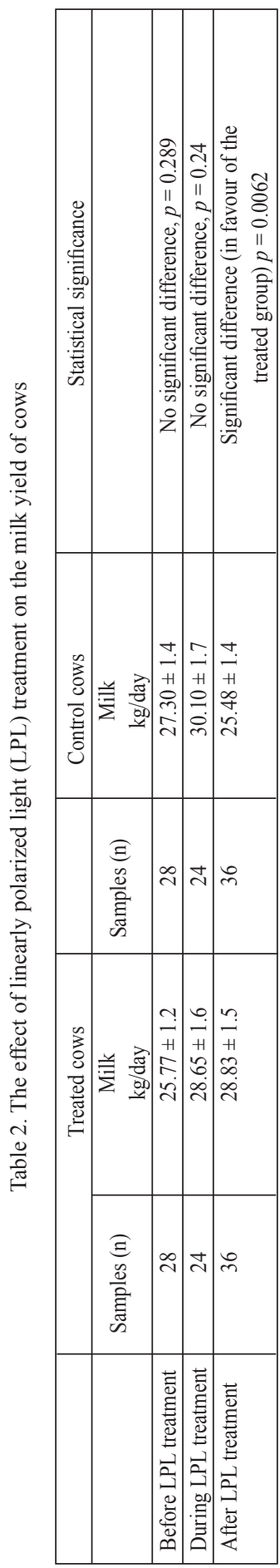

of cows with LPL emitted by the EFLITE lamp provided the following proven benefits: the SCC of milk significantly decreased and the milk yield significantly increased. The SCC decreases also after the successful antibiotic treatment of mastitis, as has been reported (Oliver et al. 2003). It must be emphasized, however, that in our experiment this favourable result was achieved without the use of drugs. Antibiotic resistance represents a serious problem affecting the use of antimicrobial products. Corti et al. (2003) studied the drug resistance data of the most important bovine mastitis pathogens in Switzerland. The antibiotics were chosen for the investigation on the basis of their licenses for intramammary application in that country. Only $53 \%$ of the coagulase-negative Staphylococcus strains were sensitive to all antibiotics tested. In addition, the use of antimicrobials is followed by the excretion of residues in the milk, which requires the application of withdrawal periods (Popelka et al. 2004). These problems need not be reckoned with when using LPL treatment.

We can also state that the LPL treatment is practicable during lactation, as its use does not require any extra time or labour.

On the basis of the reduction of SCC we can safely state that the LPL treatment improves the health status of the udder as well as the quality of milk. A further hypothetical advantage to be confirmed by other studies is that the LPL treatment may reduce the incidence of subclinical and clinical mastitis and thus enables us to reduce the use of mastitis medication and save veterinary and medication costs.

\section{Účinek lineárně polarizovaného světla na produkci mléka a počty somatických buněk v mléce krav}

Použití lineárního polarizovaného světla (LPL) je v humánní medicíně uznávaná a široce využívaná terapeutická metoda k hojení ran, vředů a řady dalších kožních problémů. Polarizované světlo mobilizuje nedostatečně fungující obranné mechanismy lidského těla. Cílem této studie bylo ověřit účinek LPL na vemeno dojnic. Před začátkem experimentu nebyl u kontrolní skupiny a skupiny určené k ošetření LPL významný rozdíl v počtu somatických buněk (SCC) ve vzorcích mléka z jednotlivých struků a celkového objemu nadojeného mléka. Po dobu jednoho měsíce byly krávy 2 krát denně na 20 minut ošetřeny LPL. Před ošetřením byly průměrné počty SCC u mléka krav určených k ošetření LPL $3,47 \times 10^{5} \pm 910$ a u kontrolní skupiny 4,07 $\times$ $10^{5} \pm 920$. Po šesti týdnech byl průměrný počet SCC u ošetřené skupiny $1,32 \times 10^{5} \pm 825$ a $2,63 \times 10^{5} \pm 825$ u kontrolní skupiny, což ukazuje významný rozdíl ve prospěch ošetřené skupiny. Před ošetřením LPL byla produkce mléka u skupiny určené k ošetření $25,77 \pm 1,2 \mathrm{~kg} \cdot \mathrm{den}^{-1}$, a u kontrolní skupiny 27,30 \pm $1,4 \mathrm{~kg} \cdot \mathrm{den}^{-1}$. Po šesti týdnech byla produkce mléka u ošetřené skupiny $28,83 \pm 1,5 \mathrm{~kg} \cdot \mathrm{den}^{-1}$ a 25,48 $\pm 1,4 \mathrm{~kg} \cdot \mathrm{den}^{-1} \mathrm{u}$ kontrolní skupiny. U těchto hodnot byl také statisticky významný rozdíl 
ve prospěch ošetřené skupiny. Výsledky ukazují, že pravidelné ošetření vemene krav LPL může významně snížit SCC v mléce a zvýšit produkci mléka. Ošetření je možné provádět během období laktace bez narušení dojení.

\section{References}

BRUCKMAIER RM, ONTSOUKA CE, BLUM JW 2004: Fractionized milk composition in dairy cows with subclinical mastitis. Vet Med-Czech 49: 283-290

CORTI S, SICHER D, REGLI W, STEPHAN R 2003: Aktuelle Daten zur Antibiotikaresistenz der wichtigsten bovinen Mastitiserreger in der Schweiz (Current drug resistance data on the most important bovine mastitis pathogens in Switzerland). Schweiz Arch Tierheilkd 145: 571-575

FENYÖ M 1984: Theoretical and experimental basis of biostimulation. Opt Laser Technol 16: 209-215

FENYÖ M, MANDL J, FALUS A 2002: Opposite effect of linearly polarized light on biosynthesis of Interleukin-6 in a human B lymphoid cell line and peripheral human monocytes. Cell Biol Int 26: 265-269

KUBASOVA T, FENYÖ M, SOMOSY Z, GAZSÓ L, KERTÉSZ I 1988: Investigations on the biological effect of polarised light. Photochem Photobiol 48: 505-509

KUBASOVA T, HORVÁTH M, KOCSIS K, FENYÖ M 1995: Effect of visible light on some cellular and immune parameters. Immunol Cell Biol 73: 239-244

MESTER AF, MESTER A 1989: Wound healing. Laser Ther 1: 7-15

OLIVER SP, ALMEIDA RA, GILLESPIE BE, IVEY SJ, MOOREHEAD H, LUNN P, DOWLEN HH, JOHNSON DL, LAMAR KC 2003: Efficacy of extended pirlimycin therapy for treatment of experimentally induced Streptococcus uberis intramammary infections in lactating dairy cattle. Vet Ther 4: 299-308

ÓZSVÁRI L, FUX A, ILLÉS BC, BÍRÓ O 2003: A Staphylococcus aureus tőgygyulladás által okozott gazdasági veszteségek számszerüsítése egy nagyüzemi holstein-fríz tehenészetben (Quantification of losses caused by Staphylococcus aureus mastitis in a large-scale Holstein-Friesian dairy farm). Magy Állatorv Lapja 125: $579-584$

POPELKA P, NAGY J, POPELKA P, HAJURKA J, MARCINCAK S 2004: Antibiotic residues in milk of dairy cows after mastitis treatment. In: SMULDERS FJM and COLLINS JD (Eds.): Food safety assurance and veterinary public health. Vol. 2. Safety assurance during food processing. Wageningen Academic Publishers, Wageningen, The Netherlands, pp. 399-400

SCHUKKEN YH, WILSON DJ, WELCOME F, GARRISON-TIKOFSKY L, GONZALEZ RN 2003: Monitoring udder health and milk quality using somatic cell counts. Vet Res 34: 579-596

SEEGERS H, FOURICHON C, BEAUDEAU F 2003: Production effects related to mastitis economics in dairy cattle herds. Vet Res 34: 475-491 
